\title{
UJI KETERTARIKAN HAMA KEONG MAS (Pomacea canaliculata L.) TERHADAP BERBAGAI UMPAN PERANGKAP DI LAHAN PADI PANDANWANGI
}

\author{
Disusun oleh : \\ Yuliani **) \\ Aidannisa*)
}

\begin{abstract}
Abstrak
Keong Mas (Pomacea canaliculata L.) merupakan salah satu hama penyebab padi gagal tumbuh pada budidaya padi Pandanwangi fase vegetatif. Hama tersebut memakan bibit padi muda sehingga petani harus menyulam kembali tanaman padi. Populasi hama Keong Mas yang tinggi perlu dikendalikan agar populasi tidak semakin meningkat. Salah satu pengendalian yang dapat dilakukan adalah pengendalian hama secara terpadu (PHPT) seperti penggunaan umpan perangkap. Tujuan penelitian ini adalah untuk mengetahui ketertarikan hama Keong Mas terhadap berbagai umpan perangkap dilahan padi Pandanwangi sehingga dapat berpengaruh terhadap populasi hama Keong Mas. Penelitian ini dilaksanakan pada bulan Desember 2018 di Pusat Studi dan pengembangan plasma nutfah padi Pandanwangi lahan milik MP3C dan Fakultas sains Terapan Univeristas Suryakacana. Penelitian ini bersifat eksperimental menggunakan Rancangan Acak Lengkap terdiri dari 4 perlakuan dan 7 ulangan, yaitu: (P1) Daun Pepaya, (P2) Daun Selada, dan (P3) Ampas Kelapa dan K (Kontrol) Hasil menunjukkan bahwa pemberian umpan berpengaruh terhadap populasi hama Keong Mas. Umpan perangkap yang paling banyak menarik populasi hama Keong Mas yaitu P1 (15.89) dan P2 (14.23) dan yang paling rendah adalah Kontrol (Larutan Ragi) yaitu sebanyak 0.76 .
\end{abstract}

Kata kunci: Pandanwangi, Hama, Keong Mas, PHPT, Umpan Perangkap.

\begin{abstract}
Golden apple snail (Pomacea canaliculata L.) is one of the plant diseases cause of the fragrance of Pandanwangi vegetatif phase. The diseases consume green rice that the farmer have to embroidered green rice back. The population of golden apple snail are raised, we have to be managed to decrease the population. One of the way to control the population is control the diseases are integrated (PHPT) as the use of traps. The aim of this research is to know the interest of golden snail dieseas to any traps in Pandanwangi field that can influental to the golden snail dieseas population. This Reasearch was carried out on Desember 2018 at he center of development Pandanwangi rice germplasm owned by MP3C and the Suryakancana University, Applied Science Faculty. This reasearch is eksperimental was conducted RAL (Completely Randomize Design) with 4 (four) Treatments, and 7 (seven) replications. (P1) Papaya Leaves, (P2) Lettuce Leaves, and (P2) Coconut Pulp dan K (Control) The results showed that the feeding effect affected the Golden Apple Snail population. The most interesting trap bait for the Golden Apple Snail population is P1 (15.89) and P2 (14.23) and the lowest is Conrol (Yeast Solution) which is 0.76.
\end{abstract}

Keywords: Pandanwangi, Pest, Golden Apple Snail, PHPT, Trap bait.

*) Alumni Fakultas Sains Terapan UNSUR

**) Dosen Fakultas Sains Terapan UNSUR 


\section{PENDAHULUAN}

Padi Pandanwangi merupakan padi varietas lokal Kabupaten Cianjur yang termasuk kedalam jenis padi bulu (javanica). Padi pandanwangi memiliki umur tanam yang cukup panjang yaitu sekitar 145-155 hari dengan tinggi tanaman mencapai $168 \mathrm{~cm}$ (MP3C, 2015). Tumbuh optimal apabila ditanam didataran sedang dengan ketinggian 450800 meter diatas permukaan laut di 7 lokasi Kecamatan di Kabupaten Cianjur, yaitu Warungkondang, Cugenang, Gekbrong, Cianjur, Cilaku, Cibeber dan Campaka (MP3C, 2015).

Beberapa faktor yang mempengaruhi hasil dalam budidaya padi Pandawangi kadangkala tidak sesuai dengan yang diinginkan. Salah satu penyebab penurunan hasil adalah adanya gangguan Organisme Pengganggu Tanaman (OPT) diantaranya adalah hama, penyakit dan gulma (Sugeng, 2001).

Produktifitas padi salah satunya ditentukan oleh terbebasnya OPT tanaman pada fase vegetatif, salah satu hama yang banyak menyerang padi Pandanwangi pada fase vegetatif adalah hama Keong Mas (Suparman, 2018). Keong Mas merupakan siput air tawar yang diintroduksikan dari Amerika ke Indonesia sejak tahun 1980-an. Keong Mas hidup pada kolam, rawa, dan lahan yang selalu tergenang termasuk sawah (Suharto dan Kurniawati, 2009).

Menurut Suharto dan Kurniawati (2009) hama Keong Mas menyerang tanaman padi dengan cara melahap bagian pangkal muda dalam waktu satu malam sehingga menyebabkan adanya batang yang terpotong ditandai dengan adanya sisa potongan daun yang mengambang dipermukaan air dan mengaharuskan petani untuk menyulam kembali tanamannya (Putra dan Zein, 2016).

Upaya pengendalian hama Keong Mas dilahan padi Pandanwangi dilakukan dengan menerapkan konsep pengendalian hama terpadu (Suparman, 2018). Penggunaan moluskisida dalam mengendalikan Keong Mas sudah tidak dianjurkan karena akan menyebabkan kematian Keong Mas, kemudian Keong Mas akan meninggalkan cangkangnya dilahan yang dapat melukai kaki petani (Handayani, 2013).

Salah satu upaya yang dilakukan adalah pengendalian secara mekanik yaitu dengan menggunakan berbagai umpan perangkap untuk mengendalikan hama Keong Mas.

Keong Mas memiliki manfaat, salah satunya yaitu menjadi bahan pakan unggas (Saputra et al., 2018). Selain itu, Keong Mas digunakan sebagai bahan baku pembuatan MOL (mikroorganisme lokal) (Rosmawaty et al., 2018). Siklus hidup keong mas disajikan pada gambar 1 .

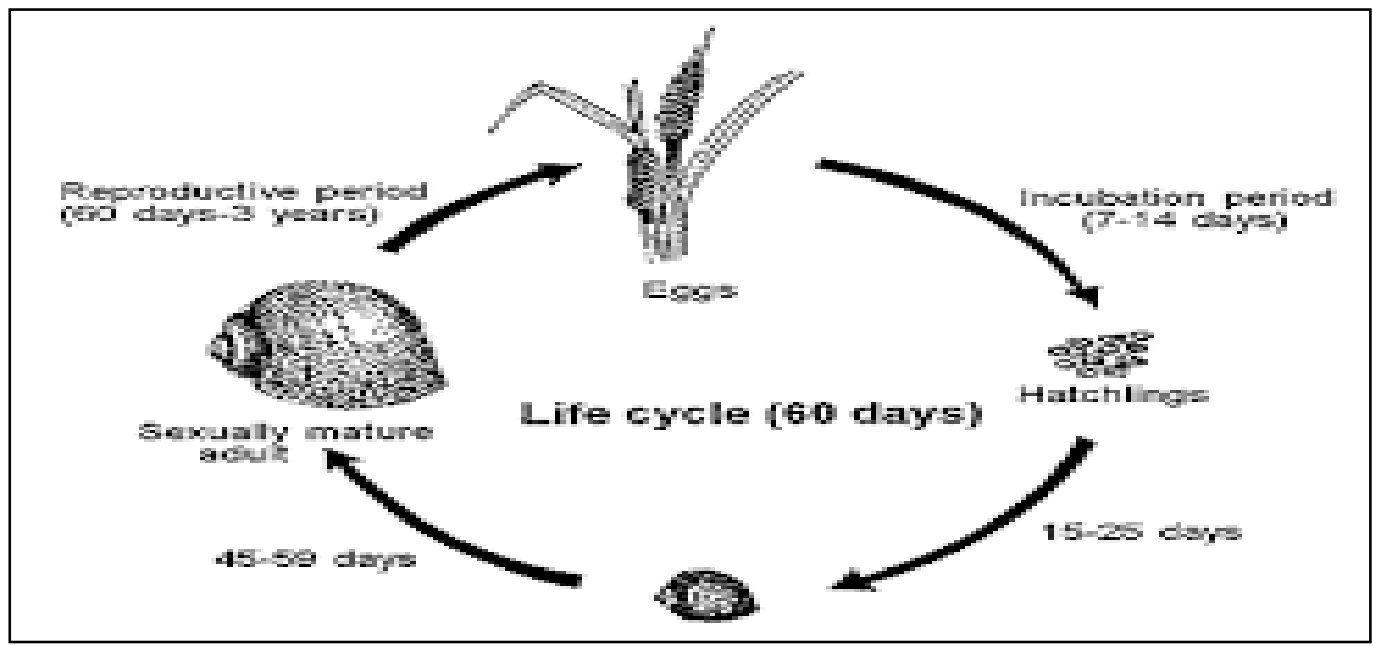

Gambar 1. siklus hidup Keong Mas. 
Keong mas memiliki siklus hidup selama 60 hari untuk menjadi keong dewasa. Fase yang paling membahayakan yaitu pada keong dewasa.

Penggunaan berbagai umpan perangkap untuk mengendalikan hama Keong Mas dilahan padi Pandanwangi belum pernah dilakukan, oleh sebab itu penelitian mengenai uji ketertarikan hama Keong Mas terhadap berbagai umpan perangkap berupa ragi kering, Daun Pepaya, Daun Selada dan Ampas Kelapa ini penting untuk dilakukan dengan tujuan untuk mengetahui berbagai umpan perangkap yang dapat menarik hama Keong Mas di lahan padi Pandanwangi.

Tujuan penelitian ini adalah untuk mengetahui ketertarikan hama Keong Mas terhadap berbagai umpan perangkap dilahan padi Pandanwangi sehingga dapat berpengaruh terhadap populasi hama Keong Mas.

\section{METODE PENELITIAN}

\section{Waktu dan tempat}

Penelitian ini dilaksanakan di Pusat Studi dan Pengemabangan Plasma Nutfah Lahan milik MP3C dan Fakultas Sains Terapan Uiversitas Suryakancana
Cianjur, Kampung Sedong Kec. Cianjur, pada bulan Desember 2018.

\section{Alat dan Bahan}

Alat yang digunakan anatra lain botol plastik ukuran $350 \mathrm{ml}$, kain tileu, gunting, pisau, sendok teh, ember, tali rapia, patok kayu, kertas label, alat tulis, kamera. Bahan-bahan yang digunakan dalam penelitian ini antara lain: ragi tape, gula pasir, air hangat, Daun Pepaya, Daun Selada dan Ampas Kelapa.

\section{Metode Penelitian}

Penelitian ini merupakan penelitian eksperimental, menggunakan Rancangan Acak Lengkap (RAL) dengan 4 perlakuan dan 7 ulangan, yaitu: $(\mathrm{K})$ kontrol berupa larutan ragi, (P1) Daun Pepaya, (P2) Daun Selada, dan (P3) Ampas Kelapa. dengan penelitian dilakukan disatu petak lahan padi Pandanwangi MP3C yang memiliki usia pertanaman padi masa vegetatif.

\section{Pelaksanaan Penelitian}

a. Penentuan lokasi penelitian lokasi penelitian ditentukan yaitu lahan yang memiliki umur pertanaman padi masa vegetatif.

b. Pembuatan denah tata leatak percobaan

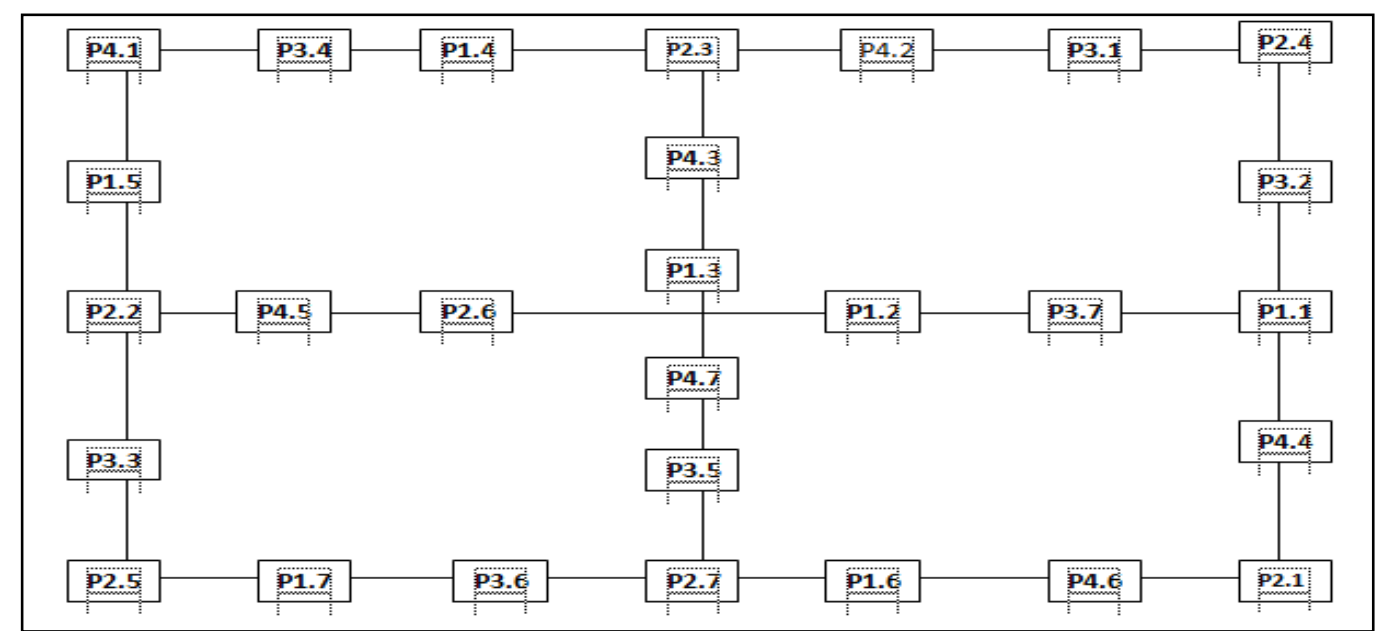

Gambar 2. Denah tata letak percobaan 
c. Pembuatan Kontrol negatif (Larutan Ragi), dibuat dengan cara melarutkan 1 sendok teh ragi dengan 250 air hangat.
d.Pembuatan umpan perangkap P3 (Ampas Kelapa) dengan cara $100 \mathrm{gr}$ ampas kelapa disungkup dengan menggunakan kain tileu.

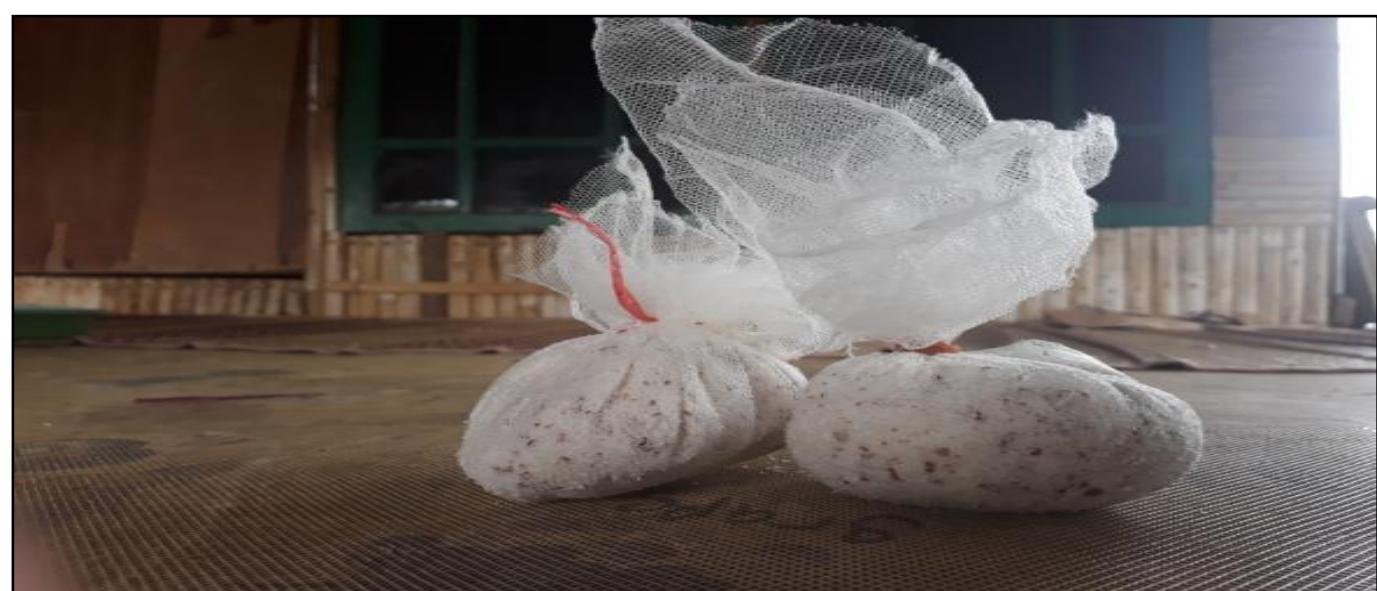

Gambar 3. Pembuatan umpan perangkat.

e. peletakkan perlakuan

Perlakuan diletakkan pada titik berdasarkan denah tata letak yang telah dibuat sebelumnya. Peletakkan umpan dilakukan pada sore hari.

\section{f. Pengamatan}

Pengamatan dilakukan setiap pagi selama 5 hari. Umpan perlakuan diganti setiap hari dan pengamatan dilakukan pada pagi hari, hasil pengamatan dicatat dalam sebuah formulir pengamatan.

\section{Pengambilan data}

Data yang diambil dan dikumpulkan dalam penelitian ini yaitu jumlah populasi keong mas disatu lahan padi Pandanwangi.

\section{Analisis Data dan Pengujian Hipotesis}

Data yang diperoleh dalam penelitian ini diolah menggunakan komputer dengan bantuan Software SPSS data dianalisis ANOVA taraf $\alpha 5 \%$, kemudian data diuji lanjut dengan uji DMRT.

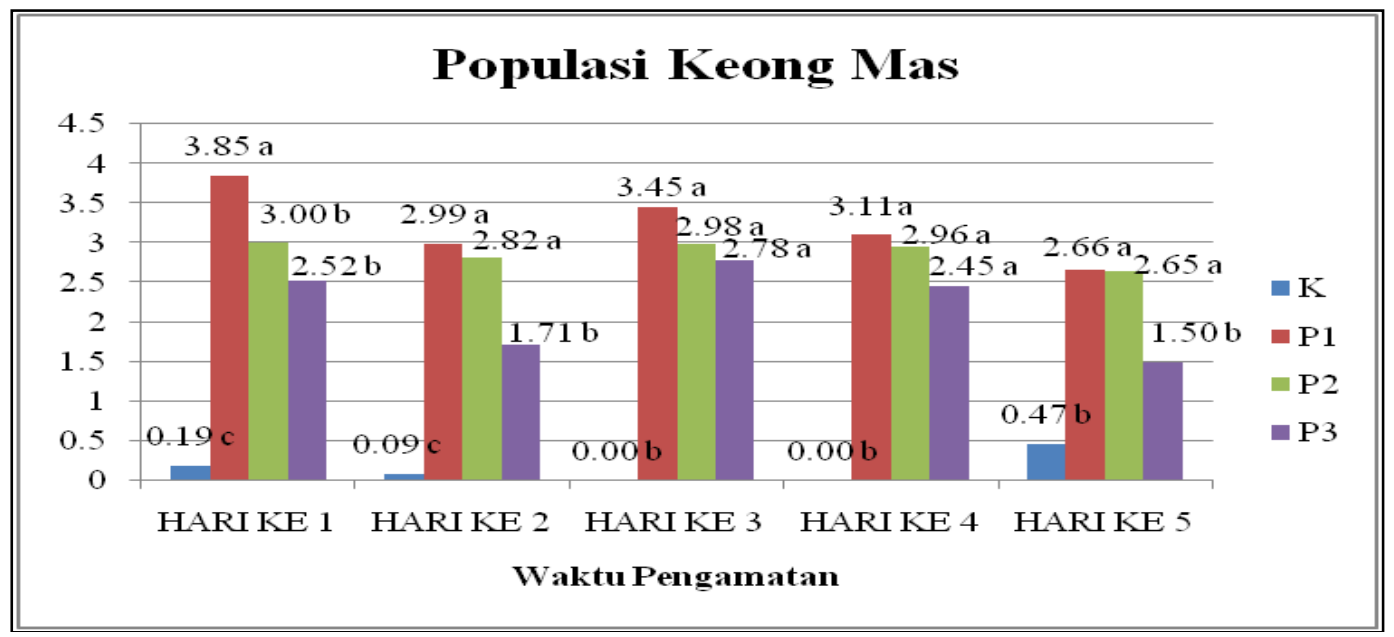

Gambar 4. Histogram uji DMRT populasi hama Keong Mas setiap hari pengamatan. 


\section{HASIL DAN PEMBAHASAN}

Parameter yang diamati pada penelitian ini adalah populasi hama Keong Mas (Pomacea canaliculata L.) terhadap berbagai umpan perangkap dilahan padi Pandanwangi. Disajikan pada (gambar 3).

Terlihat pada (gambar 3) bahwa pada hari kesatu pengamatan menarik populasi Keong Mas paling tinggi untuk perlakuan P1, P2 dan P3 dibandingkan dengan hari lainnya, hal ini diduga disebabkan karena belum adanya tindakan pemungutan Keong Mas sebelum penelitian dilakukan. Selain itu, diduga karena melimpahnya populasi Keong Mas dilahan, sesuai dengan Isnaningsih dan Marwoto (2011) yang menyatakan bahwa faktor utama yang membuat keberadaan Keong Mas melimpah dialam karena memiliki daya adaptasi yang tinggi sehingga dapat hidup diberbagai habitat.

Penurunan populasi Keong Mas terjadi dihari kedua pengamatan, hal ini diduga karena sudah adanya tindakan pemungutan Keong Mas pada hari sebelumnya. Namun pada hari ketiga pengamatan populasi Keong Mas mengalami peningkatan kembali, hal ini diduga karena adanya Keong Mas yang terbawa oleh aliran air dari petakan sawah yang lain sesuai dengan pernyataan Wiratno et al. (2011) bahwa Keong Mas memiliki mobilitas yang bahwa pada hari kesatu pengamatan menarik populasi Keong Mas paling tinggi untuk perlakuan P1, P2 dan P3 dibandingkan dengan hari lainnya, hal ini diduga disebabkan karena belum adanya tindakan pemungutan Keong Mas sebelum penelitian dilakukan. Selain itu, diduga karena melimpahnya populasi Keong Mas dilahan, sesuai dengan Isnaningsih dan Marwoto (2011) yang menyatakan bahwa faktor utama yang membuat keberadaan Keong Mas melimpah dialam karena memiliki daya adaptasi yang tinggi sehingga dapat hidup diberbagai habitat.

Penurunan populasi Keong Mas terjadi dihari kedua pengamatan, hal ini diduga karena sudah adanya tindakan pemungutan Keong Mas pada hari sebelumnya. Namun pada hari ketiga pengamatan populasi Keong Mas mengalami peningkatan kembali, hal ini diduga karena adanya Keong Mas yang terbawa oleh aliran air dari petakan sawah yang lain sesuai dengan pernyataan Wiratno et al. (2011) bahwa Keong Mas memiliki mobilitas yang tinggi karena mudah meyebar akibat terbawa oleh aliran air.

Pada hari keempat dan kelima pengamatan populasi Keong Mas mengalami penurunan diduga disebabkan karena adanya tindakan pengendalian yang dilakukan mampu menekan populasi Keong Mas sampai hari kelima pengamatan (Handayani, 2013).

Pada pengamatan hari kesatu diperoleh hasil perlakuan P1 berbeda nyata dengan perlakuan P2, P3 dan Kontrol, hal ini diduga karena P1 (Daun Pepaya) memiliki bentuk daun yang lebar yang dijadikan sebagai tempat berlindung bagi Keong Mas sesuai dengan pernyataan Tombuku et al. (2014) bahwa Keong Mas akan meletakkan diri pada perlakuan yang memiliki bentuk daun lebar dan tulang daun keras, ketertarikan hama Keong Mas terhadap Daun Pepaya diduga sebagai makanan juga sebagai tempat berlindung, sejalan dengan Wiresyamsi dan Haryanto (2008) bahwa kehadiran batang atau Daun Pepaya pada petakan sawah mampu menarik kehadiran Keong Mas sebanyak 56.73 ekor/petak dibandingkan dengan umpan lainnya.

Perlakuan P2 (Daun Selada) berbeda nyata dengan P1 (Daun Pepaya), P3 (Ampas Kelapa) dan Kontrol, hal ini diduga pada umpan perangkap selada Keong Mas menjadikan Daun Selada sebagai makanannya karena Keong Mas memiliki ketertarikan tersendiri terhadap umpan yang disediakan.

Pada pengamatan hari kedua diperoleh hasil perlakuan P1 dan P2 tidak berbeda nyata, hal ini diduga karena P1 (Daun Pepaya) dan P2 (Daun Selada) memiliki kandungan senyawa volatil yang mirip seperti yang terkandung pada bibit padi, senyawa tesebut pertama kali terdeteksi oleh organ olfactory keong mas 
kemudian keong mas akan mencari inang yang sesuai (Hamzah, 2014) sehingga keong mas memiliki ketertarikan yang sama terhadap umpan tersebut. Selain itu, diduga karena adanya kandungan protein yang dijadikan sebagai energi untuk Keong Mas, sesuai pernyataan Hamzah (2014) bahwa Adanya kandungan protein dalam daun gamal mampu menarik hama Keong Mas karena dijadikan sebagai sumber energi oleh Keong Mas.

Perlakuan P3 (Ampas Kelapa) menunjukkan hasil yang berbeda nyata dengan perlakuan lainnya, hal ini disebabkan karena umpan Ampas Kelapa yang diletakkan hanya dijadikan sebagai tempat untuk menempelkan dirinya. Perlakuan Kontrol (Larutan Ragi) berbeda nyata dengan ketiga perlakuan lainnya, hal ini sebabkan karena sulitnya Keong Mas untuk menjangkau Larutan Ragi tersebut.

Hari ketiga dan hari keempat pengamatan Perlakuan P1 (Daun Pepaya), P2 (Daun Selada) dan P3 (Ampas Kelapa) ketiganya menunjukkan hasil yang tidak berbeda nyata, hal tersebut diduga disebabkan karena Keong Mas sudah menemukan makanan yang sesuai untuk dirinya. Menurut Elfazuri (1993) dalam Saputra et al. (2018) mengelompoknya individu yang bergerak disebabkan karena ketertarikan terhadap makanan dan tempat berlindung. Perlakuan Kontrol berbeda nyata dengan Perlakuan P1, P2 dan P3 hal ini karena tidak ada Keong Mas yang terperangkap pada Kontrol tersebut.

Hari kelima pengamatan menunjukkan hasil perlakuan P1 (Daun Pepaya) dan P2 (Daun Selada) tidak berbeda nyata. Sama halnya dengan perlakuan P3 dan Kontrol menujukkan hasil yang tidak berbeda nyata. Namun, perlakuan Kontrol (Larutan Ragi) menunjukkan adanya peningkatan populasi Keong Mas dibandingkan dengan hari sebelumnya, hal ini diduga karena pada hari terakhir pengamatan banyak ditemukan Keong Mas yang berukuran kecil sehingga diduga Keong Mas yang berukuran kecil itulah yang tertarik dan masuk kedalam umpan perangkap larutan ragi.

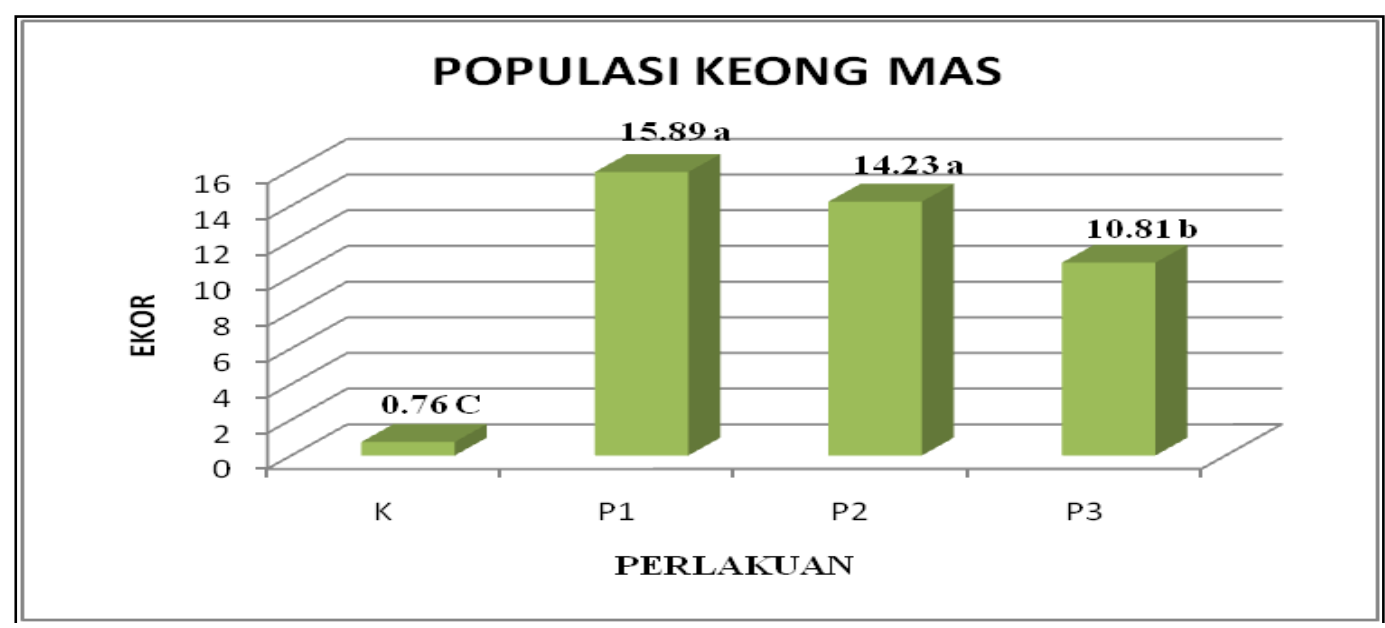

Gambar 5. Hitogram Uji DMRT Populasi Keong Mas.

Gambar 4 menunjukkan bahwa Perlakuan P1 (Daun Pepaya) dan P2 (Daun Selada) menunjukkan hasil yang tidak berbeda nyata, perlakuan P1 menarik hama Keong Mas sebanyak 15.89 ekor dan perlakuan P2 (Daun Selada) menarik hama Keong Mas sebanyak 14.23 ekor. Hal ini diduga karena adanya karakteristik yang sama yang dimiliki oleh Daun Pepaya dan Daun Selada dalam menarik hama Keong Mas. P1 (Daun Pepaya) memiliki kandungan senyawa metabolit sekunder yaitu dari golongan terpenoid (Anggrahini et al., 2013).

Senyawa Terpenoid merupakan komponen tanaman yang memberikan 
bau khas pada tanaman, senyawa tersebut pada umumnya terdapat bebas dalam jaringan tanaman, tidak terikat dengan senyawa lain, diantaranya terdapat sebagai glikosida, ester dari asam organik dan dalam beberapa hal terikat dengan protein (Sari et al., 2018) senyawa monoterpenoid dari golongan terpenoid umumnya bersifat volatile yang merupakan senyawa dengan aroma yang khas dan pada umumnya bersifat atraktan (Sari et al., 2018) diduga ketertarikan hama Keong Mas terhadap Daun Pepaya dan Daun Selada yaitu karena adanya senyawa volatile tersebut yang memberikan aroma dan pertama kali terdeteksi oleh organ penciuman hama Keong Mas, kemudian Keong Mas langsung merespon untuk mencari inang yang sesuai (Hamzah et al., 2011).

Selain itu, berdasarkan uji fitokimia yang dilakukan oleh Astuti (2009) Daun Pepaya mengandung flavonoid, saponin, dan alkaloid. Senyawa itu merupakan senyawa yang bersifat moluskisida. Namun, jika dilihat dari pola makan Keong Mas terhadap Daun Pepaya pada waktu pengamatan tidak menujukkan adanya reaksi negatif dari senyawa-senyawa tersebut, hal itu terlihat dari preferensi makan Keong Mas terhadap Daun Pepaya yang terus menerus sejak hari pertama hingga hari terakhir pengamatan. Sejalan dengan Hamzah et al. (2014) adanya kandungan senyawa - senyawa seperti alkaloid, flavonoids, saponin, tannin, steroids pada daun gamal tidak memberikan pengaruh negatif pada pola makan Keong Mas.

Daun Pepaya memiliki bentuk daun yang lebar sesuai dengan pernyataan Tombuku et al. (2014) bahwa Keong Mas akan meletakkan diri pada perlakuan yang memiliki bentuk daun lebar dan tulang daun keras, ketertarikan hama Keong Mas terhadap Daun Pepaya diduga sebagai makanan juga sebagai tempat berlindung Hal ini sesuai dengan pendapat Wiresyamsi dan Haryanto (2008) bahwa kehadiran batang atau Daun Pepaya pada petakan sawah mampu menarik kehadiran Keong Mas sebanyak 56.73 ekor/petak dibandingkan dengan umpan lainnya.

Berdasarkan hasil pengamatan Keong Mas tertarik terhadap umpan Daun Selada diduga karena memiliki tekstur daun yang lunak sehingga ketertarikannya sebagai makanan. Sesuai dengan pernyataan Budiyono (2006) bahwa Keong Mas umumnya menyukai tanaman yang masih muda dan lunak. Dalam 100 g selada terkandung energi 15 kalori, karbohidrat 2,87 g, protein 1,36 g, dan lemak 0,15 g. Siregar et al. (2015) diduga kandungn protein dalam selada mampu menjadi sumber energi untuk keong mas meskipun tidak sebesar kandungan protein dalam bibit padi yaitu sebesar 14.39 (Hamzah et al., 2014).

Perlakuan P3 (Ampas Kelapa) menujukkan hasil yang berbeda nyata dengan perlakuan P1 (Daun Pepaya), P2 (Daun Selada) dan kontrol. Perlakuan ini menarik populasi hama Keong Mas sebanyak 10.81ekor. Hal ini diduga disebabkan karena perlakuan Ampas Kelapa dibuat dengan menggunakan kain tileu sehingga Keong Mas hanya menempelkan diri dan menghisap kandungan nutrisi yang terdapat pada Ampas Kelapa. Berdasarkan pengamatan terlihat ada beberapa umpan Ampas Kelapa yang kainnya sobek.

Ampas Kelapa memiliki kandungan nutrisi yaitu potein sebesar $5.78 \%$, lemak 38,24\% dan serat kasar 15,07\% (Putri, 2010). Diduga kandungan lemak tersebut menyebabkan adanya senyawa volatile (Aziz et al., 2018) senyawa itu yang memberikan aroma khas pada Ampas Kelapa, sehingga sama halnya seperti senyawa volatil pada Daun Pepaya dan Daun Selada yang menarik hama Keong Mas. Selain itu, diduga karena adanya kandungan protein yang menyebabkan Keong Mas tertarik terhadap umpan tersebut karena terpenuhinya kebutuhan gizi Keong Mas, 
meskipun tidak sebesar kandungan protein dalam bibit padi, Daun Pepaya serta Daun Selada.

Populasi Keong Mas terendah yaitu pada perlakuan Kontrol berupa Larutan Ragi. Pembuatan umpan larutan fermentasi ragi dan gula menggunakan bahan berupa satu sendok gula, satu sendok Larutan Ragi dan air hangat untuk setiap perlakuaannya yang dimasukkan kedalam botol ukuran $350 \mathrm{ml}$. Pemanfaatan gula pada perlakuan yaitu adanya fermentasi gula mengeluarkan beberapa senyawa kimia seperti etanol, asam laktat, dan hidrogen, selain itu fermentasi juga menghasilkan senyawa lain seperti asam butirat dan aseton (Astuti et al., 2011)

Umpan perangkap fermentasi gula dan ragi ini efektif digunakan sebagai insektisida sesuai dengan penelitian Bangun (2017) penggunaan ragi dan gula untuk menarik nyamuk aides aegypty dimana memanfaatkan organ sensorsi nyamuk. Akan tetapi, berdasarkan pengamatan pada penelitian ini Keong Mas tidak banyak tertarik terhadap umpan fermentasi yang berisi larutan fermentasi gula dan ragi ini, hanya Keong Mas yang berukuran kecil yang masuk kedalam perlakuan ini, diduga karena ukuran mulut botol yang kecil tetapi berdasarkan pengamatan ada beberapa keong yang naik keatas botol dan mencium aroma dari larutan fermentasi tersebut.

\section{SIMPULAN}

Dari hasil penelitian ini dapat disimpulkan bahwa penggunaan umpan perangkap dilahan padi Pandawangi berpengaruh terhadap populasi hama Keong Mas. Umpan perangkap yang paling tinggi menarik hama Keong Mas yaitu perlakuan P1 (Daun Pepaya) dan P2 (Daun Selada) dimana hasilnya tidak berbeda nyata karena memiliki sifat atraktan berupa senyawa volatil yang dapat menarik hama Keong Mas dan umpan tersebut dijadikan sebagai makanan bagi hama Keong Mas. Perlakuan yang paling rendah menarik hama Keong Mas adalah kontrol (Larutan Ragi). Umpan perangkap yang paling baik digunakan untuk mengendalikan hama Keong Mas dilahan padi Pandanwangi adalah Daun Pepaya dan Daun Selada.

\section{DAFTAR PUSTAKA}

Anggrahini, D.N.D., R. Roza dan Fitmawati. 2013. Aktifitas Antibakteri Ekstrak Daun Pepaya (Carica papaya L.) Terhadap Eschercia coli dan Salmonella thypi. Skripsi. Universitas Riau Kampus Bina Widya. Pekanbaru.

Astuti, S.D. 2009. Efek Ekstrak Etanol 70 $\%$ Daun Pepaya (Carica papaya L.) terhadap Aktivitas AST \% ALT pada Tikus Galur Wistar Setelah Pemberian Obat Tuberkulosis (isoniazid \% rifampisin). Skripsi. Universitas Setia Budi. Bandung.

Azis, R. dan I. R. A. R. Akolo. 2018. Karakteristik Tepung Ampas Kelapa. Journal Of Agritech Science (JASc). 2(2): 104-116.

Hamzah, S., Sjam, dan S. Hasan. 2014. Pengendalian Keong Mas dengan Atraktan Alam Daun Gamal dan Pemanfaatannya sebagai bahan Baku Compled Feed. Program Pasca Sarjana. Program Studi Sistem-Sistem Pertanian. Universitas Hasanuddin.

Handayani, D. 2013. Uji Efektifitas Pengendalian Keong Mas (Pomacea canaliculata L.) Padi Sawah dengan Menggunakan Rendaman Air Kapur Sirih (CaCo3) dan Ekstrak Daun Ubi Karet (Manihot glaziovii M.A). Jurnal Edu Bio Tropika. 1(2): 21120.

MP3C (Masyarakat Pelestari Padi Pandanwangi Cianjur). 2015. Buku Persyaratan Indikasi 
Geografis Beras Padi pandanwangi Cianjur. Cianjur.

Putra, S. dan S. Zein. 2016. Pengaruh Variasi Konsentrasi Ekstrak Serai (Andropogon Nardus) Terhadap Mortalitas Hama Keong Mas (Pomacea caniculata L.). Jurnal Pendidikan Biologi. 7(1): 10-15.

Putri, M. F. 2010. Tepung ampas kelapa pada umur panen 11-12 bulan sebagai bahan pangan sumber kesehatan. Jurnal kompetensi teknik. 1(2): 97-105.

Rosmawaty, T., S. Sutriana dan Murdiono. 2018. Aplikasi MOL Keong Mas dan TSP dalam Meningkatkan Produksi Tanaman Kacang Tanah (Arachis hypogaea L.) Prosiding Seminar Nasional Dalam Rangka Dies Natalis UNS Ke 42 Tahun 2018. Surakarta. 1017.

Saputra, K., S. Sutriyono dan B. Brata. 2018. Populasi dan Distribusi Keong Mas (Pomacea canaliculata L.) sebagai Sumber Pakan Ternak pada Ekosistem Persawahan Di Kota Bengkulu. Jurnal Sain Peternakan Indonesia. 13(2): 189-201.

Sari, D. E., R. Arma dan Y. Asdar. 2018. Preferensi Pomacea canaliculata Terhadap Perangkap Atraktan Alami Pada Pertanaman Padi. Jurnal Agrominansia. 3(2): 101108.

Sugeng. 2001. Bercocok Tanam Aneka Polowijo. Aneka Ilmu. Semarang. Suharto, H. dan N. Kurniawati. 2007. Keong mas dari hewan peliharaan menjadi hama utama padi sawah. Jurnal Balai Besar Penelitian Padi. 385-403.
Suparman, U. 2018. Komunikasi Pribadi. Ketua MP3C, Cianjur, Indonesia.

Tombuku, I.,J.B. Kaligis., M. Moningka dan M. Manuenke. 2014. Potensi Beberapa Tanaman Atraktan Dalam Pengendalian Hama Keong Mas (Pomacea canaliculata L.) Pada Tanaman Padi Sawah di Desa Tonsewer Kecamatan Tompaso II. Cocos Jurnal Ilmiah Fakultas Pertanian Universitas Sam Ratulangi. 4(1).

Wiratno, W., M. Rizal dan I. W. Laba. 2017. Potensi ekstrak tanaman obat dan aromatik sebagai pengendali keong mas. Buletin Penelitian Tanaman Rempah dan Obat. 22(1): 54-64.

Wiresyamsi, A. dan H. Haryanto. 2017. Pengendalian Hama Keong Mas (Pomacea Analiculata L.) Dengan Teknik Perangkap Dan Jebakan. CROP AGRO, Scientific Journal of Agronomy. 1(2): 137-143. 